\title{
EVALUATE THE POTENTIAL SNPS FOR BREEDING SELECTION OF WHITE SPOT SYNDROME VIRUS RESISTANCE IN LITOPENAEUS VANNAMEI
}

\author{
Nguyen Thi Kim Lien ${ }^{1, \bowtie}$, Nguyen Van Tung ${ }^{1}$, Duong Chi Thanh ${ }^{1}$, Nguyen Thu Hien ${ }^{1}$, Nguyen Ngoc \\ Lan $^{1}$, Nguyen Thi Thanh Ngan ${ }^{1}$, Nguyen Huy Hoang ${ }^{1}$, Trinh Thi Trang ${ }^{2}$, Nguyen Huu Ninh ${ }^{3}$, Nguyen \\ Huu Hung ${ }^{3}$
}

${ }^{I}$ Institute of Genome Research, Vietnam Academy Science and Technology

${ }^{2}$ Vietnam National University of Agriculture, Ministry of Agriculture and Rural Development

${ }^{3}$ Research Institute for Aquaculture No. 3, Ministry of Agriculture and Rural Development

${ }^{\circledR}$ To whom correspondence should be addressed. E-mail: ntkimlienibt@gmail.com

Received: 15.02 .2019

Accepted: 27.5.2019

SUMMARY

White spot syndrome virus (WSSV) is a dangerous virus causing great damage to shrimp farming. Many genes related to disease resistance mechanisms have been identified and studied. In this study, we amplified and sequenced nine fragments of DNA harboring SNPs in the genes involved in WSSV resistance of whitelegged shrimp, Litopenaeous vannamei. Allele frequencies at the SNP loci were recorded and calculated by SPSS statistical software (version 22) in the study groups: the disease shrimp (were infected with WSSV and died) and the resistance shrimp (were infected with WSSV but survived). Six SNPs (in AIF, ALF1, HAE, P53, $R a b 5 B$, and TRAF6 genes) were in accordance with Hardy-Weinberg Equilibrium (HWE) $(p>0.05)$ while three SNPs (in $A L F 2, B G B$, and $C A L)$ were not $(p<0.05)$. For $A I F$ and $A L F 1$ genes, the frequencies of GG and $\mathrm{CC}$ genotypes were significantly different between two groups and were associated with an decreased resistance with WSSV compared to the AA and TT genotypes ( $p=0.021$ and $\mathrm{p}=0.017$, respectively). The G and $\mathrm{C}$ alleles were associated with a decreased resistance with WSSV $(\mathrm{p}=0.000$ and $p=0.001$, respectively). For $H A E$ gene, the frequency of TT genotype was significantly different between two groups and was associated with a increased resistance with WSSV compared to the TC+CC genotype $(\mathrm{OR}=68.750 ; 95 \% \mathrm{CI}$ : $11.462-412.381 ; p=0.000$ ). For $R a b 5 B$ gene, the frequency of CC genotype was significantly different between two groups and was associated with an increased resistance with WSSV compared to the TT genotype in all three tested models $(\mathrm{p}<0.05)$. The $\mathrm{C}$ allele was associated with an increased resistance with WSSV $(\mathrm{OR}=$ 3.974; 95\% CI: $1.754-9.003 ; p=0.001)$. The above evaluation results suggested that the potential SNPs of these $A I F, A L F 1, H A E$, and Rab5B genes can be used as the molecular markers for breeding selection the resistance to white spot disease in white-legged shrimp L. vannamei.

Keywords: Litopenaeus vannamei, molecular marker, SNP, WSSV resistancy

\section{INTRODUCTION}

Aquaculture is a major economic resource in many countries. However, aquaculture in general and shrimp farming in particular has been dramatically affected by many pathogenic diseases, mainly caused by viruses. In these viruses, the virus that causes white spot disease (WSSV - White Spot Syndrome Virus) and serious damages to the shrimp farming, is a dangerous virus. To combat the viruses, shrimp has formed many mechanisms against the invasion and spread of the virus with the participation of many different genes. Disease resistance mechanisms known as enhancing the expression and activating of the genes in the immune system or the genes play a part in the signaling pathways that activate the activity of target genes to fight the infection of viruses and the genes associated in the apoptosis of cell to limit the spread of the virus...

A large number of genes, including genes coding for proteins of the Toll/IMD-NF-kB signaling pathway (Spatzle/Tolls/MyD88/Pell/TRAF6/Dosal), small $\mathrm{G}$ proteins, pattern recognition receptors (Ctype lectin), apoptosis proteins (AIF, caspases, CYC, $\mathrm{P} 53 . .$.$) , proteins implicated in immune response$ (cathepsin, HSP, lysozyme)... have been studied. 
Research of Liu et al. (2016) showed high transcript levels of the Toll, IMD, Pelle, IAP1, TRAF6, ALF genes and suggested that the expression of these genes plays an important role in Toll/IMD signaling pathway. Function of TRAF6 (tumor necrosis factor receptor associated factor 6 ) has been studied in the immune responses of invertebrates and showed that TRAF6 was adjusted up to 2.7 folds in the hepatopancreas after 3 hours infected with WSSV. This finding indicated that TRAF6 associated with antimicrobial responses through the regulation of expression of AMP genes (Wang et al., 2011). Zhang et al. (2012) reported that MyD88 plays a role in antimicrobial and antiviral responses in $L$. vannamei. Li et al. (2017) identified the role of p53 in the adjustment of immediate-early (IE) of antimicrobial peptide (AMPs) when L. vannamei infected with WSSV. These antimicrobial peptides include antilipopolysaccharide factors (ALF1, ALF2), crustin, lysozyme and penaeidin. Studies have shown the enhanced expression of ALF when WSSV infection shift from latent to acute phase (Li et al., 2013). Zhao et al. (2015) found that Rab5, Rab6, Rab7 (the members of small $\mathrm{G}$ protein family) proteins were over-expressed in shrimp after WSSV infection. The results demonstrated the role of these proteins in the immune responses of shrimp. Besides, the vascular endothelial growth factors (VEGF) that take part in the promotion of cell growth, cell migration, vascular enhancement, vascular formation, and the reactions between host cell and pathogen contribute to confer resistance to shrimp against WSSV (Tammela et al., 2004).

Apoptosis is often considered as a type of antiviral immune response. This is an important defense mechanism of cell to suppress the replication and spread of virus (Everett, McFadden, 1999; Koyama et al., 2000). This process occurs at early stage after viral infection and before viral replication leading to the production and the spread of virus would be severely impacted. AIF, caspases, and cytochrome c (CYC) are three factors involved in the onset of apoptosis (Marsden et al., 2002). A special fragment on the caspase gene (fragment 3 ) has been identified in WSSV-resistant shrimp. The expression level of five caspase genes were reported that are highly sensitive to infection with WSSV. The expression of $A I F, C Y C$, and caspase 3 genes were significantly increased in WSSV-infected shrimps. The results suggested that $A I F, C Y C$, and caspase 3 genes plays an important role in immune responses against WSSV infection (Hu, Yao, 2016). In shrimp,
ROS (reaction oxygen species) are produced during defense reactions and responds to virus infection $(\mathrm{Ji}$ et al., 2011). ROS are then rapidly eliminated by antioxidant enzymes, which may participate in the production of reactive oxygen compounds used in the destruction of pathogens (Campa-Córdova et al., 2002). When the balance between the production and elimination of ROS is disturbed, excessive production of ROS leads to cellular damage and subsequently apoptosis (Legeay et al., 2005). In addition, inhibitor of apoptosis (IAP) protein family members also participate in many cellular processes such as apoptosis and response to pathogens. Leu and colleagues (2012) evaluated that IAP1 plays a major role in the regulation of apoptosis of shrimp.

In this study, we evaluated the SNPs in some genes that related to WSSV resistance to identify the potential SNPs for the selection breeding of whitelegged shrimp.

\section{MATERIALS AND METHODS}

Shrimp samples including healthy (uninfected with WSSV, 30 samples), disease (infected with WSSV and died, 30 samples), and resistance samples (infected with WSSV and survived, 30 samples) were collected from Research Institute for Aquaculture No. 3.

Total DNA of shrimp samples were extracted by Gene JET Genomic DNA Purification kit (Thermo, USA). The extraction steps were performed according to the manufacturer's instructions.

PCR reactions were carried out using $10 \mathrm{pmol}$ of each primer (Table 1) and $20 \mathrm{ng}$ of DNA as template in $25 \mu \mathrm{l}$ reactions containing $1 \mathrm{X}$ Dream Taq buffer, $0.2 \mathrm{mM}$ dNTPs, $1.5 \mathrm{mM} \mathrm{MgCl}_{2}$, and $1 \mathrm{U}$ Dream Taq (Thermo, U.S.A.). The cycle conditions were $95^{\circ} \mathrm{C}$ for $1 \mathrm{~min}$ and 35 cycles of $95^{\circ} \mathrm{C}$ for $10 \mathrm{~s}, 58^{\circ} \mathrm{C}-$ $62^{\circ} \mathrm{C}$ for $30 \mathrm{~s}$ and $72^{\circ} \mathrm{C}$ for $30 \mathrm{~s}$, followed by a final extension step of $72^{\circ} \mathrm{C}$ for $10 \mathrm{~min}$. The PCR amplification was carried out on an Eppendorf Mastercycler EP gradient (USA Scientific, Inc).

The PCR products were purified using the Qiaquick PCR purification kit (Qiagen, Germany) and sequenced directly using an ABI PRISM 3500 (U.S.A.). The sequences were aligned and compared to the reference sequences in GenBank using BioEdit software version 7.2.5.

Results were recorded and analyzed by SPSS statistics software (version 22) to calculate the 
frequency of alleles among the study groups. Chisquared test $(\chi 2)$ was used to test whether allele distribution of each SNP follows Hardy-Weinberg Equilibrium (HWE). Three models (additive, dominant, recessive) for associations of the studied
SNPs with WSSV resistance were tested. The normal distribution was used to estimate the confidence interval for the ratio of alleles. All statistical probabilities used in the study were conducted with $95 \%$ confidence $(95 \% \mathrm{CI})$.

Table 1. Primer pairs were used in this study.

\begin{tabular}{llll}
\hline Primer & 5' sequence & 3' sequence & Size of products \\
\hline ALF1 & GCTGACATCATCCCCAACT & CTGGAATGTGCTATGGTG & $1000 \mathrm{bp}$ \\
ALF2 & ACTAACCCTTTCGCTCCCACCCAC & TATTGGATGAGGTATCAACATTCGC & 750 bp \\
AIF & TCTAGGGGAGTAGGAGGAATCA & GTGGACCACTGAGAAGGTCA & $580 \mathrm{bp}$ \\
BGB & TACGGCTGCTCCCGAACT & TACGAGGCAACATCGAAATA & $560 \mathrm{bp}$ \\
CAL & TAGAGATCGTATTACGTCAAAGGA & GGTCAAGAACTCGTGGAACACCT & $250 \mathrm{bp}$ \\
HAE & GCAGATTCCGAGCATTTACGC & TAGAACACTTTGAAACTGCCACC & $750 \mathrm{bp}$ \\
P53 & AGTCGTGTTTTTAGTCTTAAGTC & CAGGAAGTGGTAGAGCCTTCAATCA & $1500 \mathrm{bp}$ \\
RAB5B & GGAGACCTCTGCTAAGACTGCTATG & CTGTGCTGGCTGGTTATTGG & $350 \mathrm{bp}$ \\
TRAF6 & CTGACCCTTTAGTGGACGCAT & AGGTTCCTGTGCTGGGTTGA & $250 \mathrm{bp}$ \\
\hline
\end{tabular}

\section{RESULTS AND DISCUSSION}

In this study, nine primer pairs have been used to amplify SNPs in shrimp samples. PCR products were electrophoresed on $1 \%$ agarose gel. Results on Fig. 1 showed that a single band with the expected size in all the samples (750 bp band for $H A E$ gene, $1500 \mathrm{bp}$ band for P53 gene, and $250 \mathrm{bp}$ band for TRAF6 gene, respectively).

The PCR products were purified and sequenced directly in ABI PRISM 3500 system.
The data were compared with reference genes of L. vannamei in GenBank. The comparison results of gene sequences at SNP positions were shown in Fig. 2, 3, 4, 5.

Allele frequencies of SNP loci were recorded and calculated in each group of shrimp samples. Results on Table 2 showed that six SNPs (in $A I F$, $A L F 1, H A E, P 53, R a b 5 B$, and TRAF6 genes) were in accordance with Hardy-Weinberg Equilibrium (HWE) $(p>0.05)$ while three SNPs (in $A L F 2, B G B$, and $C A L)$ were not $(p<0.05)$.

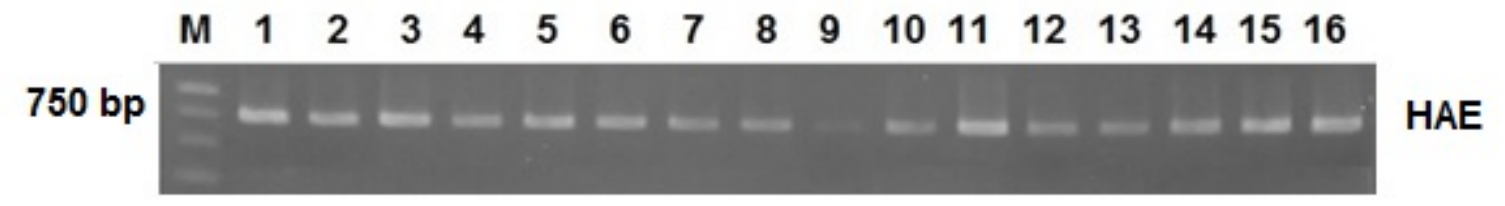

$1500 \mathrm{bp}$
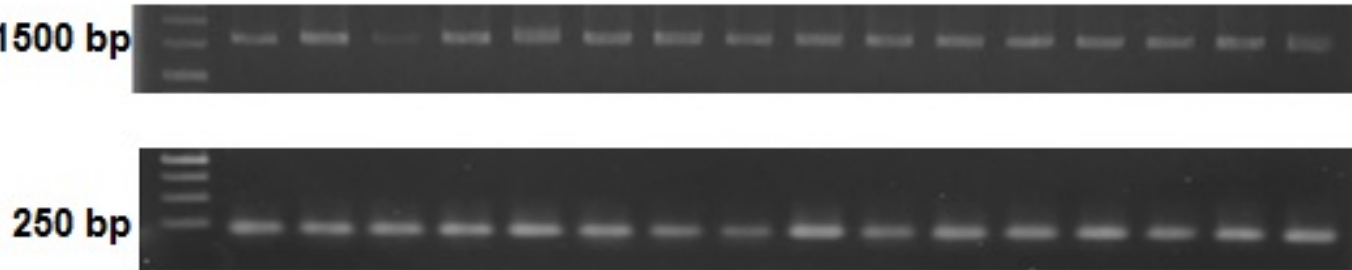

TRAF6

Figure 1. Electrophoresis results of PCR products on $1 \%$ agarose gel. (First section: Amplified PCR products of $H A E$ gene from shrimp samples. Second section: Amplified PCR products of $p 53$ gene from shrimp samples. Third section: Amplified PCR products of HAE gene from shrimp samples). 
Nguyen Thi Kim Lien et al.

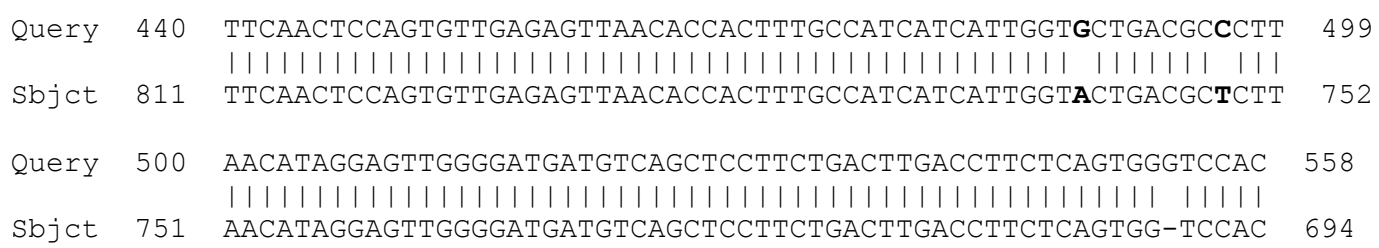

Figure 2. Comparison results with the cDNA sequence of AIF gene ( $L$. vannamei apoptosis inducing factor - KX096891) SNP locates at position 601 on cDNA sequence of AlF gene.

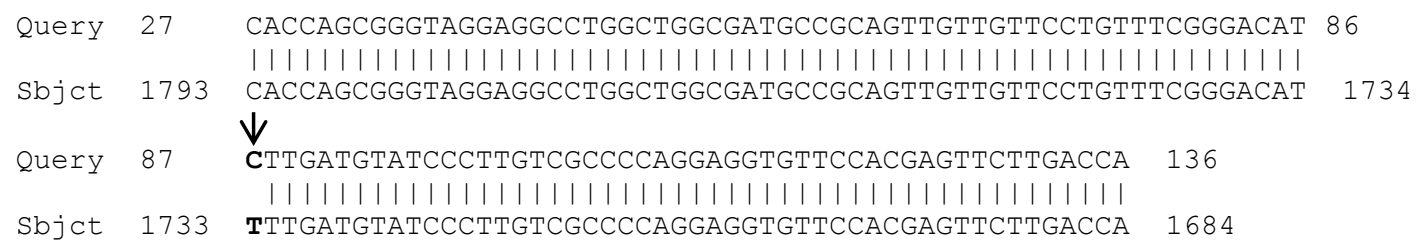

Figure 3. Comparion results with the cDNA sequence of cathepsin $L$ gene (L. vannamei cathepsin $L-Y 13924)$. SNP locates at position 212 on cDNA sequence of CAL gene.

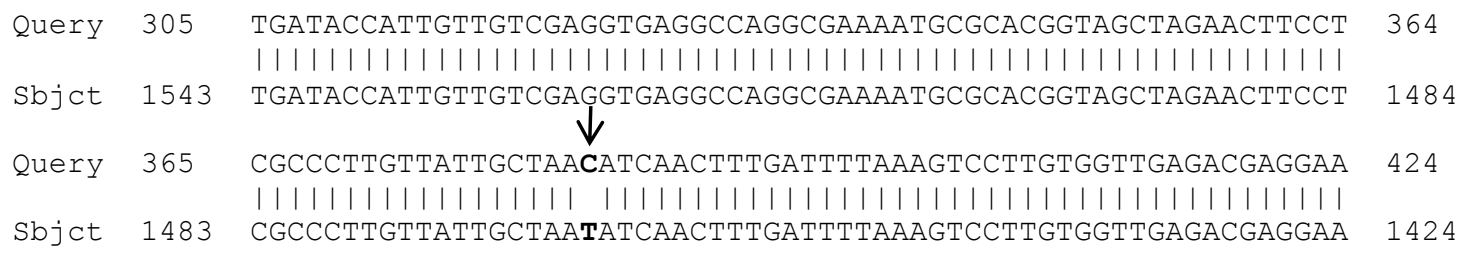

Figure 4. Comparion results with the cDNA sequence of HAE gene (L. vannamei hemocyanin subunit L1 - KF193058). SNP locates at position 1465 on cDNA sequence of HAE gene.

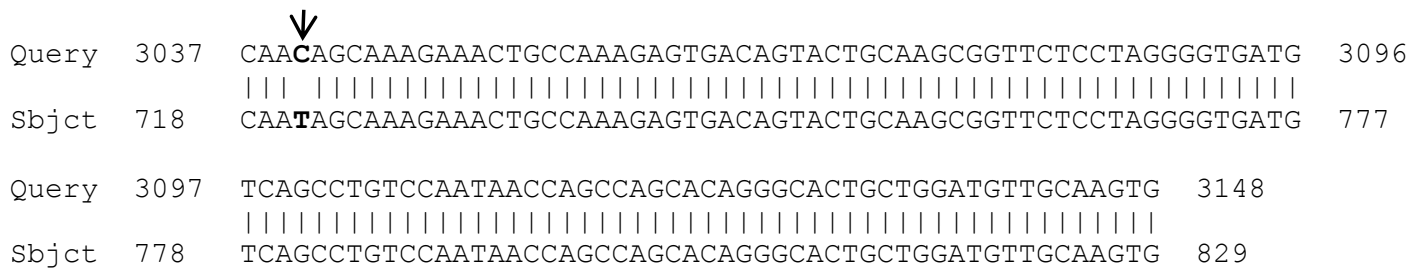

Figure 5. Comparion results with the cDNA sequence of Rab5B gene (L. vannamei Rab5B - JQ901103). SNP locates at position 524 on cDNA sequence of $R a b 5 B$ gene.

In this study, we assessed the correlation between genotype and phenotype of some SNPs in genes involved in WSSV resistance in shrimp, $L$. vannamei. The results indicated that no significant difference in allele frequencies between disease and resistance group was found in P53 and TRAF6 genes in all three tested models $(\mathrm{p}>0.05)$ (the data not showed). In Table 3 showed a significant difference of genotypes obtained in the additive model of four genes (AIF, ALF1, HAE, and Rab5B with $\mathrm{p}=0.000)$. For $A I F$ and $A L F 1$ genes, the frequencies of $\mathrm{GG}$ and $\mathrm{CC}$ genotypes were significantly different between two groups and were associated with a decreased resistance with WSSV compared to the AA and TT genotypes ( $p=0.021$ and $\mathrm{p}=0.017$, respectively). The $\mathrm{G}$ and $\mathrm{C}$ alleles were associated with a decreased resistance with WSSV $(\mathrm{OR}=0.184 ; 95 \%$ CI: $0.074-0.456 ; \mathrm{p}=0.000$ and $\mathrm{OR}=0.229 ; 95 \%$ CI: $0.096-0.545 ; p=0.001$, respectively). For $H A E$ gene, the frequency of TT genotype was significantly different between two groups and was associated with a increased resistance with WSSV compared to the $\mathrm{TC}+\mathrm{CC}$ genotype $(\mathrm{OR}=68.750$; 95\% CI: $11.462-412.381 ; p=0.000)$. For Rab5B 
gene, the frequency of $\mathrm{CC}$ genotype was significantly different between two groups and was associated with an increased resistance with WSSV compared to the TT genotype in all three tested models $(\mathrm{OR}=14.400,95 \%$ CI: 2.714-118.109, $p=$
$0.004 ;$ OR $=4.800,95 \%$ CI: $1.372-16.795, \mathrm{p}=$ 0.011 ; and $\mathrm{OR}=7.765,95 \% \mathrm{CI}: 1.529-39.442, \mathrm{p}=$ 0.007, respectively). The $\mathrm{C}$ allele was associated with an increased resistance with WSSV (OR = 3.974; 95\% CI: $1.754-9.003 ; p=0.001$ ).

Table 2. General information on the studied single nucleotide polymorphisms (SNPs).

\begin{tabular}{llllll}
\hline Gene & Allele & Type of variant & $\begin{array}{l}\text { HWE in disease } \\
\text { group } \\
(\mathbf{p})\end{array}$ & $\begin{array}{l}\text { HWE in resistance group } \\
(\mathbf{p})\end{array}$ & $\begin{array}{l}\text { HWE in all population } \\
(\boldsymbol{p})\end{array}$ \\
\hline ALF1 & T/C & p.Phe51Phe & 0.02 & 0.09 & 0.54 \\
$A L F 2$ & G/T & p.Glu54Asn & 0.02 & 0.01 & 0.00 \\
$A I F$ & A/G & p.Ser201Gly & 0.41 & 0.00 & 0.07 \\
$B G B$ & T/C & p.Gly158Gly & 0.39 & 0.01 & 0.00 \\
CAL & T/C & p.Phe71Ser & 0.74 & 0.00 & 0.00 \\
HAE & A/G & p.lle489Val & 0.00 & 0.00 & 0.87 \\
Rab5B & T/C & p.lle175His & 0.97 & 0.51 & 0.22 \\
P53 & - /A & 5'UTR & 0.61 & 0.26 & 0.26 \\
TRAF6 & A/G & p.lle500Val & 0.09 & 0.66 & 0.15 \\
\hline
\end{tabular}

HWE: Hardy-Weinberg equilibrium was checked by Chi-squared test.

Table 3. Associations of SNPs with WSSV resistance.

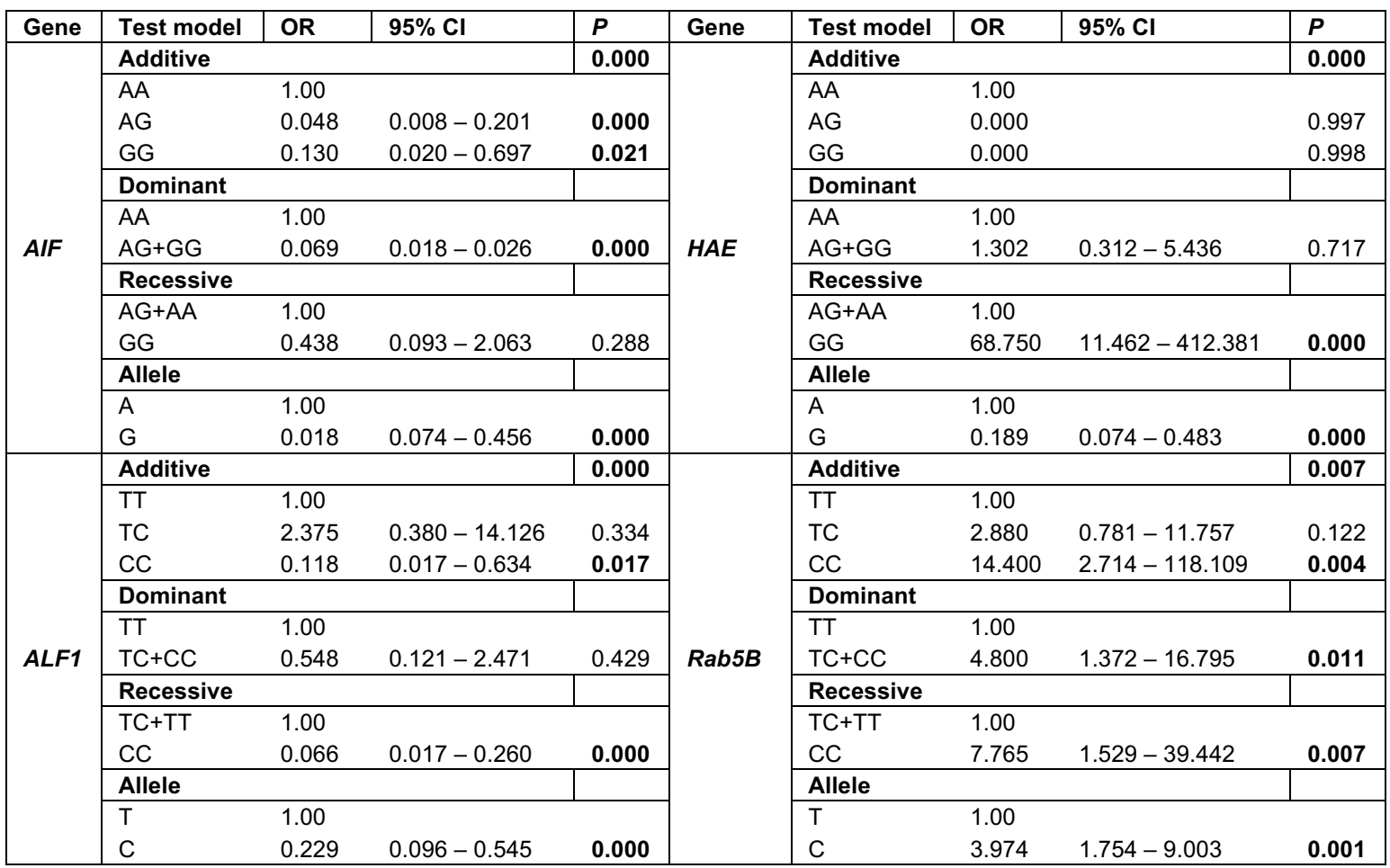

95\% Cl: $95 \%$ confidence interval of odds ratio; OR: Odds ratio.

The above evaluation results suggested that the potential SNPs of these AIF, ALF1, HAE, and Rab5B genes can be used as the molecular markers for breeding selection the resistance to white spot disease in white-legged shrimp $L$. vannamei. 


\section{CONCLUSION}

In this study, we assessed the correlation between genotype and phenotype of some SNPs in genes involved in WSSV resistance in shrimp, $L$. vannamei. Six SNPs (in $A I F, A L F 1, H A E, P 53$, $R a b 5 B$, and TRAF6 genes) were in accordance with Hardy-Weinberg Equilibrium (HWE) $(p>0.05)$ while three SNPs (in $A L F 2, B G B$, and $C A L$ ) were not $(p<0.05)$. Four SNPs in $A I F, A L F 1, H A E$, and Rab5B genes had significant differences of genotypes between disease and resistance groups. The evaluation results suggested that the potential SNPs of these $A I F, A L F 1, H A E$, and Rab5B genes can be used as the molecular markers for breeding selection the resistance to white spot disease in white-legged shrimp L. vannamei.

Acknowledgements: This work is supported by Ministry of Agriculture and Rural Development for research grants "Research on the creation of materials to serve for WSSV resistance breeding in white-legged shrimp".

\section{REFERENCES}

Campa-Córdova AI, Hernández-Saavedra NY, De Philippis R, Ascencio F (2002) Generation of superoxide anion and SOD activity in haemocytes and muscle of American white shrimp (Litopenaeus vannamei) as a response to $\beta$-glucan and sulphated polysaccharide. Fish Shellfish Immunol 12: 353-366.

Everett H, McFadden G (1999) Apoptosis: an innate immune response to virus infection. Trends Microbiol 7: $160 \mathrm{e} 5$.

Hu WY, Yao CL (2016) Molecular and immune response characterizations of a novel AIF and cytochrome $\mathrm{c}$ in Litopenaeus vannamei defending against WSSV infection. Fish Shellfish Immunol 56: 84-95.

Ji PF, Yao CL, Wang ZY (2011) Reactive oxygen system plays an important role in shrimp Litopenaeus vannamei defense against Vibrio parahaemolyticus and WSSV infection. Dis Aquat Organ 96(1): 9-20.

Koyama AH, Fukumoria T, Fujitaa M, Irieb H, Adachi A (2000) Physiological significance of apoptosis in animal virus infection. Microbes Infect 2: 1111-1117.

Legeay A, Achard-Joris M, Baudrimont M, Massabuau JC, Bourdineaud JP (2005) Impact of cadmium contamination and oxygenation levels on biochemical responses in the Asiatic clam Corbicula fluminea. Aquat Toxicol 74(3): 242-253.

Leu JH, Chen YC, Chen LL, Chen KY, Huang HT, Ho
JM, Lo CF (2012) Litopenaeus vannamei inhibitor of apoptosis protein 1 (LvIAP1) is essential for shrimp survival. Dev Comp Immunol 38: 78-87.

Li SH, Zhang XI, Sun Z, Li FH, Xiang JH (2013) Transcriptome analysis on Chinese shrimp Fenneropenaeus chinesis during WSSV acute infection. PLOS One 2013: 8

Li S, Wang Z, Li F, Yu K and Xiang J (2017) A novel vascular endothelial growth factor receptor participates in white spot syndrome virus infection in Litopenaeus vannamei. Front Immunol 8: 1457.

Liu Y, Song Lei, Sun Y, Liu T, Hou F, Liu X (2016) Comparison of immune response in Pacific white shrimp Litopenaeus vannamei, after knock down of Toll and IMD gene in vitro. Dev Comp Immunol 60: 41-52.

Marsden VS, O'Connor L, O'Reilly LA, Silke J, Metcalf D, Ekert PG, et al. (2002) Apoptosis initiated by Bcl-2regulated caspase activation independently of the cytochrome c/Apaf-1/caspase-9 apoptosome. Nature 419(6907): 634-637.

Tammela T, Enholm B, Alitalo K, Paavonen K (2005) The biology of vascular endothelial growth factors. Cardiovasc Res 65: 550-563.

Wang PH, Wan DH, Gu ZH, Deng XX, Weng SP, Yu XQ, He JG (2011) Litopenaeus vannamei tumor necrosis factor receptor-associated factor 6 (TRAF6) responds to Vibrio alginolyticus and white spot syndrome virus (WSSV) infection and activates antimicrobial peptide genes. Dev Comp Immunol 35: 105-114.

Zhang S, Li C-Z, Yan H, Qiu W, Chen Y-G, et al. (2012) Identification and function of myeloid differentiation factor 88 (MyD88) in Litopenaeus vannamei. PLoS ONE 7(10): e47038.

Zhao YZ, Chen XL, Zeng DG, Yang CL, Peng M, Chen $\mathrm{XH}$ (2015) Molecular cloning, characterization, and expression of Rab5B, Rab6A, and Rab7 from Litopenaeus vannamei (Penaeidae). Genet Mol Res 14(3): 7740-7750.

Zou H, Li Y, Liu X, Wang X (1999) An APAF1.cytochrome c multimeric complex is a functional apoptosome that activates procaspase-9. J Biol Chem 274(17): 11549-11556.

\section{Abbreviation}

AIF: apoptosis inducing factor

ALF1: anti-lipopolysaccharide factor

AMPs: antimicrobial peptide

BGB: $\beta$-1,3-glucan-binding protein

CAL: cathepsin L

CAR: carboxypeptidase 
CYC: cytochrome c

DNA: deoxyribonucleotides acid

GTPase: guanosine triphosphatase

HAE: haemocyanin

HSP: heat shock protein

IAP: inhibitor of apoptosis protein

IE: immediate-early
IMD: immune deficiency

PCR: polymerase chain reaction

SNP: single nucleotide polymorphism

SPSS: statistical package for the social sciences

TRAF6: TNF receptor associated factor 6

VEGF: vascular endothelial growth factor

WSSV: white spot syndrome virus

\section{ĐÁNH GIÁ CÁC CHỈ THỊ SNP TIỀM NĂNG CHO CHỌN GIỐNG KHÁNG VIRUS GÂY BỆNH ĐỐM TRẮNG Ở TỔM THẺ CHÂN TRẮNG (LITOPENAEUS VANNAMEI)}

\section{Nguyễn Thị Kim Liên ${ }^{1}$, Nguyễn Văn Tụng ${ }^{1}$, Dương $C^{2}$ Thành $^{1}$, Nguyễn Thu Hiền ${ }^{1}$, Nguyễn Ngọc Lan $^{1}$, Nguyễn Thị Thanh Ngân ${ }^{1}$, Nguyễn Huy Hoàng ${ }^{1}$, Trịnh Thị Trang ${ }^{2}$, Nguyễn Hữu Ninh ${ }^{3}$, Nguyễ்n Hữu Hùng}

${ }^{I}$ Viện Nghiên cứu hệ gen, Viện Hàn lâm Khoa học và Công nghệ Việt Nam

${ }^{2} H o ̣ c$ Viện Nông nghiệp Việt Nam, Bộ Nông nghiệp và Phát triển nông thôn

${ }^{3}$ Viện Nghiên cứu nuồi trồng thủy sản 3, Bộ Nông nghiệp và Phát triển nông thôn

\section{TÓM TẮT}

WSSV (virus gây bệnh đốm trắng) là một loại virus nguy hiểm và là nguyên nhân gây thiệt hại nghiêm trọng cho nghề nuôi tôm. Nhiều gen liên quan đến các cơ chế kháng bệnh đã được xác định và nghiên cứu. Trong nghiên cứu này, chúng tôi đã khuếch đại và giải trình tự 9 đoạn gen mang các điểm SNPs trên các gen liên quan đến tính kháng bệnh đốm trắng trên tôm thẻ chân trắng, L. vannamei. Tần suất alen tại các điểm SNPs được ghi nhận và tính toán bằng phần mềm thống kê sinh học SPSS (version 22) ở các nhóm tôm nghiên cứu: nhóm tôm bị bệnh (được cảm nhiễm nhân tạo với WSSV và chết) và nhóm tôm kháng bệnh (được cảm nhiễm nhân tạo với WSSV nhưng vẫn khỏe mạnh). Sáu điểm SNP trên các gen $A I F, A L F 1, H A E, P 53, R a b 5 B$, và TRAF6 phù hợp với trạng thái cân bằng Hardy-Weinberg $(\mathrm{HWE})(\mathrm{p}>0,05)$ và ba $\mathrm{SNP}$ trên các gen $A L F 2$, $B G B$ và $C A L$ không phù hợp $(\mathrm{p}<0,05)$. Kết quả đánh giá trên gen $A I F$ và $A L F 1$ cho thấy có sự khác biệt có ý nghĩa thống kê $(\mathrm{p}<0,05)$ về tần suất kiểu gen $\mathrm{GG}$ và $\mathrm{CC}$ giữa nhóm tôm bệnh và nhóm tôm kháng. Các alen $\mathrm{G}$ và $\mathrm{C}$ có liên quan đến sự giảm tính kháng với WSSV ( $\mathrm{p}=0.000$ và $p=0.001$, tương ứng). Tần suất kiểu gen TT giữa nhóm tôm kháng và nhóm tôm bệnh cũng có sự khác biệt có ý nghĩa thống kê $(\mathrm{p}<0,05)$ ở điểm SNP trên gen $H A E$ so với kiểu gen $\mathrm{TC}+\mathrm{CC}$. Đặc biệt ở điểm SNP trên gen Rab5B cho thấy sự khác biệt và sự gia tăng tính kháng với bệnh một cách có ý nghĩa thống kê $(\mathrm{p}<0,05)$ của tần suất kiểu gen $\mathrm{CC}$ giữa nhóm tôm kháng và nhóm tôm bệnh so với kiểu gen $\mathrm{TT}$ ở cả ba mô hình đánh giá. Các kết quả đánh giá trên chỉ ra rằng có thể sử dụng các chỉ thị trên gen $A I F, A L F 1, H A E$ và Rab5B trong chọn giống kháng bệnh đốm trắng ở tôm thẻ chân trắng $L$. vannamei.

Tù̀ khóa: Chỉ thị phân tử, tính kháng WSSV, Litopenaeus vannamei, SNP 